\title{
MAKNA DAN NILAI BUdAYA TAPIS INUH pada masyarakat pesisir di lampung SELATAN
}

\author{
THE MEANING AND CULTURAL VALUES OF TAPIS INUH \\ IN COASTAL COMMUNITIES SOUTH LAMPUNG
}

\author{
Hary Ganjar Budiman \\ Balai Pelestarian Nilai Budaya Bandung \\ Jl.Cinambo no. 136 Ujungberung Bandung 40294 \\ e-mail: hgbudiman@gmail.com
}

\begin{abstract}
Abstrak
Penelitian ini berjudul Makna dan Nilai Budaya Tapis Inuh pada Masyarakat Pesisir di Lampung Selatan. Inuh merupakan salah satu jenis Tapis yang berkembang di tengah masyarakat beradat Sai Batin, umumnya tinggal di pesisir Lampung. Inuh dibuat dengan bahan benang sutera yang pewarnaannya menggunakan teknik celup tradisional. Pembuatan Inuh dilakukan dengan teknik tenun ikat, yaitu kain yang proses pembentukan motifnya dilakukan melalui pengikatan benang-benang. Inuh menarik untuk dikaji karena motif dan ragam hias di dalamnya menggambarkan cara pandang masyarakat pesisir terhadap lingkungannya, yang berbeda dengan masyarakat di pedalaman (beradat Pepadun). Penelitian ini difokuskan untuk menjawab apa dan bagaimana makna yang tersirat dari motif dan ragam hias yang terdapat pada Inuh, juga untuk mengetahui bagaimana penggunaan serta nilai-nilai budaya yang tekandung di dalamnya. Metode yang digunakan dalam penelitian ini adalah metode kualitatif dengan pendekatan deskriptif analitis. Penelitian ini menggunakan konsep kebudayaan fisik dan nilai budaya. Ciri khas Inuh terlihat dari motifnya yang bernuansa laut. Tapis Inuh yang dibuat secara tradisional, dewasa ini sangat sulit ditemukan karena pewarisannya tidak sembarangan. Bagi masyarakat pesisir Lampung, Inuh merepresentasikan status sosial. Semakin tinggi tingkat kerumitan Inuh, semakin tinggi status sosial pemakainya. Dilihat dari pembuatannya, Inuh mengandung nilai-nilai keuletan, kerja keras, kecermatan, dan penghargaan terhadap kaum wanita.
\end{abstract}

Kata kunci: Inuh, Sai Batin, pesisir Lampung, ragam hias, tenun ikat.

\begin{abstract}
This research entitled The Meaning and Cultural Values of Tapis Inuh in South Lampung Coastal Communities. Inuh is one kind of tapis that evolved in Sai Batin society. Inuh is made from silk material which colored by traditional dye techniques and the motif by weaving techniques. Inuh is an interesting subject, because the motif represents Coastal Communities way of life, which is different from rural communities in Lampung. This research focused to answer the implicit meaning of Inuh's motif, also to know how Inuh used in Sai Batin society and its cultural values. This research used qualitative method with descriptive analytical approach and concept of physical culture and culture value. Inuh's characteristic can be seen from a nautical motif. Nowadays Tapis Inuh, which made traditionally, is hard to find because its inheritance not given arbitrary. In Lampung Coastal Communities, Inuh represent social status. The more complex is
\end{abstract}


Inuh's motif, the more high social status it represent. In terms of making Inuh, it contained of perseverance, hard work, and frugality values, also reflected of respect for women.

Keywords: Inuh, Sai Batin, Coastal Lampung, ornament, ikat.

\section{A. PENDAHULUAN}

Umum diketahui bahwa Tapis ${ }^{1}$ merupakan kain tradisional yang khas dari masyarakat Lampung. Tapis dikenal sebagai kain tenunan yang berbentuk seperti kain sarung (senjang), dipakai pada bagian pinggang ke bawah oleh wanita Lampung. Kain ini merupakan hasil tenun benang kapas dengan motif benang emas dan benang perak (Laskio, 1997: 1 dan Firmansyah, 1996: 4). Tapis identik dengan karya budaya masyarakat beradat Pepadun (pedalaman) di Lampung. Tapis ini memiliki bermacam jenis, semisal Tapis Cucuk Andak, Tapis Limar Sekabar, Tapis Pucuk Rebung, Tapis Kaca, Tapis Jung Sarat, dan lain-lain. Dari sekian banyak jenis Tapis, dikenal pula jenis kain yang disebut sebagai Inuh. Tapis memang dikenal luas di Indonesia sebagai kain tradisional khas Lampung, namun

\footnotetext{
${ }^{1}$ Dalam beberapa litelatur, Tapis didefinisikan secara berbeda-beda. Kata "Tapis" berasal dari kata "Tapih" (Bahasa Jawa) yang artinya kain panjang (Intani, 2006: 1). Dalam perspektif Barat, khususnya jika dilihat dari aspek bahasa, kata tapis berdekatan dengan kata "Tapestries". Jika melihat pada kamus English-Indonesia, kata ini mengacu pada kata "permadani". Kemungkinan besar, secara konsep, Tapis tidak berbeda jauh dengan permadani. Misalnya, dalam Webster's New World Dictionary terdapat kata yang hampir mirip dengan "Tapis", yaitu kata "Tapestries" (bentuk jamak) atau "tapestry" (bentuk tunggal) lebih cenderung memiliki arti permadani, yaitu " $a$ heavy handwoven reversible textile used for hangings, curtains, and upholstery and characterized by complicated pictorial designs". Artinya, sebuah kain hasil tenunan tangan yang digunakan untuk hiasan, tirai, dan pelapis, ditandai dengan desain bergambar yang rumit.
}

demkian, Inuh merupakan salah satu jenis kain yang agak berbeda.

Jika Tapis identik dengan karya masyarakat Pepadun (pedalaman), Inuh justru identik dengan karya budaya masyarakat Sai Batin (pesisir). Kepopuleran Tapis dan dikenalnya Tapis secara luas membuat masyarakat pada umumnya cenderung mengkatagorisasikan Inuh ke dalam salah satu jenis Tapis. Hal ini memang tidak keliru, namun patut dicatat bahwa Inuh memiliki cara pembuatan dan pemaknaan yang agak berbeda oleh masyarakat pendukungnya, dalam hal ini masyarakat beradat Sai Batin. Meski demikian, tak bisa dipungkiri bahwa baik Inuh maupun Tapis yang dikenal luas, memiliki fungsi yang hampir sama, yaitu digunakan oleh wanita dalam upacara-upacara adat di Lampung.

Cara pembuatan Inuh dan pemaknaan masyarakat pendukungnya terhadap Inuh menjadi kajian yang menarik untuk digali. Berikut ini beberapa alasan mengapa Inuh menarik dan penting untuk diteliti. Pertama, Inuh yang berkembang di tengah masyarakat Pesisir merepresentasikan cara pandang masyarakat pesisir dan menggambarkan kemampuan mereka dalam mengembangkan sebuah karya budaya. Kedua, perlu dikemukakan di awal tulisan ini bahwa Inuh dibuat dengan cara sulam tangan dan motif-motifnya berbeda dengan motif Tapis pada umumnya. Inuh dibuat dengan sulam ikat dan merupakan satusatunya tenun ikat yang dibuat dengan tangan. Nuansa Inuh dapat dilihat dari motif dan ragam hiasnya yang bernuansa laut, sesuai dan menggambarkan pengetahuan masyarakat Sai Batin. Ketiga, Inuh dewasa ini jumlahnya amat terbatas dan tidak diproduksi dalam jumlah besar (Wawancara dengan Zulkifli Yusbir, 30 Oktober 2012). Kelangkaan yang terjadi 
pada Inuh bertolak belakang dengan Tapis yang produksinya melimpah. Hal ini menjadi penting pula untuk dikaji, mengapa terjadi kelangkaan pada kain Inuh.

Mary Louise Totton berpendapat bahwa Inuh diperkirakan sudah ada sejak abad ke-17 dan dibuat oleh Seniman Komering di Lampung Barat (Etnis Skala Brak). Asumsi ini dikemukakan oleh Totton berdasarkan pendapat ahli-ahli kain di Lampung terhadap kain Inuh yang berusia sangat tua yaitu sekitar 400 tahun. Totton menegaskan bahwa asumsi ini tentu belum final karena perlu dilakukan analisis fisik kain secara lebih ilmiah dengan metode radio karbon (Totton, 2009). Meski demikian, Totton memberikan pijakan awal bahwa Inuh memang mulai muncul dari wilayah pesisir. Asumsi ini diperkuat dengan mulai muncul dan kembali dikenalnya kain Inuh baru di wilayah Lampung Selatan pada tahun 2005. Lampung Selatan itu sendiri merupakan wilayah pesisir yang lebih dekat dengan laut. Inuh mulai diperkenalkan kembali dan diangkat di Lampung Selatan oleh salah seorang kolektor dan pengusaha kain antik bernama Zulkifli Yusbir.

Mengacu pada brosur resmi yang dikeluarkan oleh Dewan Kerajinan Daerah Lampung Selatan pada tahun 2011, Pemerintah daerah Lampung Selatan sudah mengidentikkan Inuh sebagai salah satu karya dan ciri khas masyarakat Lampung Selatan. Artinya, sepanjang tahun 2005 hingga 2011, telah terjadi perkembangan yang cukup signifikan pada keberadaan kain Inuh di Lampung Selatan. Berdasarkan kondisi tersebut dan berdasarkan kemampuan dalam proses pengumpulan data, maka penulis membatasi ruang lingkup kajian di wilayah Lampung Selatan, dengan asumsi wilayah ini merepresentasikan wilayah pesisir yang mendukung perkembangan kain Inuh. Adapun penelitian ini difokuskan untuk menjawab: (1) apa itu Inuh dan bagaimana makna yang terkandung dalam ragam hias Inuh, (2) mengapa Inuh mengalami kelangkaan, (3) bagaimana penggunaan Inuh oleh masyarakat pesisir Lampung, dan (4) nilai-nilai seperti apa saja yang terkandung pada Inuh.

\section{B. METODE PENELITIAN}

Metode yang digunakan dalam penelitian ini adalah metode kualitatif dengan pendekatan deskriptif analitis. Untuk menunjang dalam proses pengumpulan data, penulis menggunakan teknik wawancara di lapangan dan berdasarkan studi pustaka. Untuk memberi arah dalam melacak data serta menentukan pembatasan dalam pengamatan dan pengumpulan data, maka penulis menggunakan konsep ilmu-ilmu sosial. Salah satu konsep yang dipakai terkait dengan pembahasan Inuh adalah konsep kebudayaan fisik (physical culture) dan nilai budaya. Menurut para ahli, tiap kebudayaan pada umumnya mempunyai paling sedikit tiga wujud, yaitu: (1) wujud kebudayaan sebagai suatu himpunan gagasan yang merupakan wujud yang paling abstrak. Sebagai suatu himpunan gagasan, suatu kebudayaan tak dapat dilihat atau diamati, karena tersimpan dalam kepala orang yang dibawa ke manapun ia pergi; (2) wujud kebudayaan sebagai jumlah perilaku yang berpola; dan (3) wujud kebudayaan sebagai sekumpulan benda dan artifacts. Dalam konteks kebudayaan pada masyarakat pesisir Lampung, kain Inuh merupakan wujud dari sekumpulan benda dan artifacts atau kebudayaan fisik (physical culture). Dari wujudnya ini dapat dikaji nilai-nilai budaya yang terkandung sebagai representasi dari masyarakat pendukungnya dalam menghadapi perkembangan zaman dan menuju kehidupan yang lebih baik (Daeng, 2000: 45).

Nilai budaya merupakan bagian dari sistem budaya, yaitu aspek dari sistem gagasan. Dalam kaitan itu sistem nilai budaya adalah sejumlah pandangan mengenai soal-soal yang paling berharga dan bernilai dalam hidup. Karena itu 
disebut sistem nilai. Sebagai inti dari suatu sistem kebudayaan, sistem nilai budaya menjiwai semua pedoman yang mengatur tingkah laku warga pendukung kebudayaan yang bersangkutan. Pedoman tingkah laku itu adalah adat-istiadatnya, sistem normanya, aturan etikanya, aturan moralnya, aturan sopan-santunnya, pandangan hidup dan ideologi pribadi. Soal-soal yang paling tinggi nilainya dalam hidup manusia dan yang secara universal ada dalam tiap kebudayaan di dunia, menyangkut sedikitnya lima hal, yaitu: (1) soal makna hidup manusia; (2) soal makna pekerjaan, karya, dan amal perbuatan manusia; (3) persepsi manusia mengenai waktu; (4) soal hubungan manusia dengan alam sekitarnya; (5) soal hubungan manusia dengan sesama manusia. Kelima masalah yang bernilai dalam hidup tersebut itulah yang biasanya menjadi isi dari sistem nilai budaya dalam tiap kebudayaan di dunia. Persepsi dan konsepsi mengenai kelima masalah di atas bisa berbeda-beda dalam berbagai kebudayaan (Daeng, 2000:47). Adapun sistem nilai budaya merupakan tingkat yang paling abstrak dari adat. Suatu sistem nilai budaya terdiri dari konsepsi-konsepsi, yang hidup dalam alam pikiran sebagian besar warga masyarakat, mengenai hal-hal yang harus mereka anggap amat bernilai dalam hidup. Oleh karena itu, suatu sistem nilai budaya biasanya berfungsi sebagai pedoman tertinggi bagi kelakuan manusia (Koentjaraningrat, 1985: 25-31).

Sistem nilai budaya sangat erat kaitannya dengan etos kerja. Secara sederhana, kata etos dapat didefinisikan sebagai watak dasar dari suatu masyarakat. Perwujudan etos itu dapat dilihat dari struktur dan norma sosial masyarakat itu (Ensiklopedia Nasional Indonesia, 1989: 219). Sebagai watak dasar dari masyarakat etos menjadi landasan bagi perilaku diri sendiri dan lingkungan sekitarnya, yang terpancar dalam kehidupan masyarakat (Sairin, 2002:319). Salah satu cerminan dan etos masyarakat ini, setidaknya dapat dilihat dari karya budaya yang dihasilkan oleh masyarakat. Dalam konteks masyarakat pesisir Lampung, etos kerja ini terpancar dari bagaimana mereka menghasilkan dan menggunakan kain Inuh sebagai salah satu ciri khas masyarakat pesisir Lampung.

\section{HASIL DAN BAHASAN 1. Identifikasi Tapis Inuh}

Tapis yang banyak ditemui di Lampung merupakan Tapis yang identik dengan hasil karya masyarakat pedalaman Lampung (Pepadun). Hingga saat ini Tapis merupakan kain tradisional yang memiliki keanekaragaman motif dan dapat ditemukan di berbagai pelosok Lampung. Kondisi ini agak berbeda dengan Inuh yang jumlah serta keanekaragamannya masih sangat terbatas di Lampung. Inuh merupakan kain yang identik dengan hasil karya masyarakat Pesisir Lampung (Sai Batin). Nuansa Inuh dapat dilihat dari motif dan ragam hiasnya yang bernuansa laut. Perbedaan antara Tapis dan Inuh, terletak pada cara pembuatannya. Tapis dicucug, sementara Inuh dibuat dengan sulam ikat dan merupakan satu-satunya tenun ikat yang dibuat dengan tangan (Wawancara dengan Zulkifli Yusbir, 30 Oktober 2012).

Belum banyak litelatur yang mengupas dan meneliti tentang Inuh. Beberapa buku yang mengupas dan membahas tentang Inuh, justru dibuat oleh peneliti asing, seperti sebuah buku berjudul Wearing Wealth and Styling Identity (2009) yang ditulis oleh Mary Louise Totton. Dalam buku tersebut dikemukakan secara lebih teknis mengenai apa dan bagaimana bentuk kain Inuh.

Tapis Inuh adalah kain tapis yang terbuat dari lima panel yang dijahit secara bersama. Lurik tenun ikat berwarna merah bata hasil dari teknik menenun diversified plain weave berselang-seling dengan lurik berwarna biru indigo hasil dari teknik menenun warp face yang sepenuhnya tertutupi oleh sulaman benang sutra berwarna-warni (kain satin, tangkai, dan jahitan belakang) dan beberapa cermin 
applique. Garis sederhana warp face yang membatasai lurik tenun ikat ditegaskan dengan tajam dalam warna merah dan kuning, dan dihiasi dengan desain rentetan intan horizontal berukuran kecil yang dibuat dengan jarum tenun tunggal (Totton, 2009).

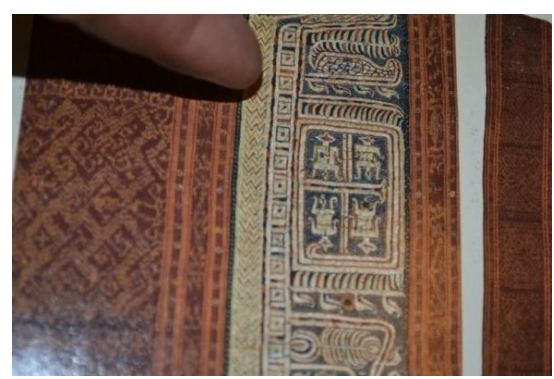

Gambar 1. Kain Inuh. Sumber: Dok. BPNP 2012.

Robert J Holmgreen dan Anita E Spertus dalam buku Early Indonesian Textiles, mendefinisikan Inuh sebagai salah satu jenis Tapis, dan secara lebih detil menyoroti unsur ragam hiasnya. Inuh merupakan representasi kelompok Tapis baru. Tapis jenis ini dikarakteristikkan dengan sebuah tenunan sentral (padahal biasanya tapis memiliki dua jalur pinggir) dan panel ikat dengan kapal yang agung atau abstraksi burgundy. Tenunan berlikuliku kecil menghiasi keliman. Pinggang ikonografi tenunannya termasuk antropomorfis yang luas, mewah, dan bertautan dengan format yang canggung. Berbeda dengan motif biasa yang menggunakan motif kapal, pohon, dan stik figur. Ragam hias pada tapis Inuh dipenuhi hiasan gelombang, makhluk-makhluk air seperti teripang, tunas sulur daun. Ragam hias ini menyimbolkan kesuburan dan geneologis. Makhluk air kecil dalam tubuhnya simbol dari generasi baru yang akan lahir, dan pucuk daun dengan untaian ekor menggambarkan penyebaran benih kehidupan baru (Holmgreen, 1989). Kata "Tapis baru" yang dikemukakan oleh Holmgreen harus dicermati lebih jauh, sangat mungkin yang dimaksud "baru" adalah Inuh baru ditemukan kembali setelah sekian lama jejaknya hilang karena tersimpan di tangan kolektor barangbarang antik (Wawancara dengan Zulkifli Yusbir, 30 Oktober 2012).

Beberapa buku yang dikeluarkan Pemerintah Daerah Lampung dan buku resmi yang dikeluarkan oleh Museum Ruwa Jurai Lampung cenderung mendefinisikan Inuh secara lebih umum dan mengkategorisasikan Inuh ke dalam salah satu jenis kain Tapis. Menurut Junaidi Firmansyah dkk, dalam bukunya yang berjudul Mengenal Sulaman Tapis Lampung (1996), disebutkan bahwa Tapis Inuh memiliki motif hias binatang, tumbuh-tumbuhan dan pilin berganda. Kain ini ditenun dengan cara pengikatan benang lungsi dalam bentuk pola hiasan tertentu yang kemudian dicelup dengan bahan pewarna, sebelum benang lungsi itu ditenun (Firmansyah dkk, 1996: 18). Berdasarkan buku yang dikeluarkan Depdikbud Lampung, dijelaskan bahwa Tapis Inuh dibuat dengan teknik tenun Pakan-Lungsi $i^{2}$ dan dipakai pada upacara adat. Ragam hias lajur dipenuhi dengan hiasan gelombang, makhluk air seperti amuba, tunas sulur daun, dan makhluk air ukuran besar. Adapun bentuk ragam hias berupa makhluk air dan sulur daun yang terdapat dalam Tapis Inuh adalah simbol dari kesuburan dan genealogis. Sementara, makhluk kecil yang nampak merupakan simbol dari cikal bakal generasi baru yang akan lahir. Adapun pucuk daun dengan untaian ekornya adalah penggambaran dari penyebaran benih kehidupan baru (Depdikbud Lampung, 1998/1999:57).

Dewan Kerajinan daerah Kabupaten Lampung Selatan berdasarkan brosur resmi yang dicetak mengungkapkan bahwa Inuh merupakan kain asli Lampung Pesisir. Inuh terkenal karena sulaman benang sutera yang dicelup dengan pewarna alam. Secara

\footnotetext{
${ }^{2}$ Lungsi adalah benang yang membujur pada kain tenunan. Pakan adalah benang yang dimasukan melintang pada benang lungsi. Pakan dan Lungsi digunakan dalam proses penenunan (Totton, 2009).
} 
umum, ragam hias yang disulam adalah flora, binatang, dan geometris. Inuh dibuat dengan tangan ahli di mana dari awal proses pembuatan-pemintalan benang, hingga menjadi Tapis Inuh, dilakukan dengan tangan, dan diproduksi secara terbatas yang membuat Inuh menjadi sesuatu yang unik dan luwes. Di zaman modern sekarang ini, tapis Inuh dibuat dengan motif dan warna yang lebih beragam tanpa mengurangi makna dan kualitas kainnya (Brosur Inuh Warisan Lampung Selatan, Dekranas Lampung Selatan).

Berdasarkan berbagai litelatur seperti yang dikemukakan di atas, Inuh dijelaskan dalam berbagai definisi. Penting kiranya untuk mengambil batasan yang jelas tentang apa itu Inuh. Berdasarkan referensi di atas dapat diambil sebuah batasan tentang Inuh, bahwa Inuh merupakan salah satu jenis Tapis yang pembuatannya dengan cara tenun $\mathrm{ikat}^{3}$ dengan menggunakan bahan benang sutera yang pewarnaannya dengan teknik celup tradisional. Ciri khas Inuh terlihat dari motifnya yang lebih bernuansa laut. Faktor yang membedakan antara Inuh dengan kain Tapis khas Pepadun adalah bahannya, Inuh menggunakan benang sutera, sementara Tapis menggunakan bahan benang perak dan emas dalam pembuatan motifnya.

Selain dilihat dari berbagai litelatur, identifikasi Inuh dapat ditinjau dari penamaannya. Inuh yang dibuat dalam bentuk aslinya sebetulnya sudah nyaris punah. Nama Inuh itu sendiri sebetulnya muncul dari ketidaktahuan beberapa pemilik kain, yang ketika ditanya, tidak mampu menjelaskan secara pasti asalusulnya. Nama Inuh berasal dari kata "Induh", yang berarti tidak tahu. Kata Induh merupakan bahasa Lampung. Pergeseran pelafalan dan nama menjadi

3 Tenun Ikat adalah kain yang proses pembentukan motifnya dilakukan melalui pengikatan benang-benang (Totton, 2009)
Inuh, juga terkait dengan beberapa peneliti dan peminat kain dari luar negeri yang kesulitan melafalkan kata "Induh", sehingga terdengar menjadi "Inuh". Dari titik itulah nama Inuh muncul (Wawancara dengan Zulkifli Yusbir, 30 Oktober 2012).

Berdasarkan keterangan yang termuat dalam Wearing Wealth and Styling Identity (2009), kain Tapis ini telah diidentifikasi berasal dari daerah Lampung Barat (Peminggir Skala Brak) kira-kira akhir abad ke-19. Meski demikian, ada kemungkinan lain bahwa kain Inuh bisa saja muncul sejak abad ke-17 yang ditenun oleh seorang seniman Suku Komering ${ }^{4}$. Asumsi ini perlu pembuktian mutakhir dengan teknik uji karbon pada kain-kain Inuh yang diperkirakan telah berusia tua, antara 300 sampai 400 tahun. Walaupun demikian, sikap skeptis harus dipertahankan terhadap tebakan umur semacam itu. Menurut beberapa catatan, Tapis Inuh hanya dipakai oleh pewaris wanita tertua pada hari pernikahannya. Dapat diduga bahwa ini merupakan sebuah contoh baik dari pelopor tenun ikat berwarna tunggal yang ditemukan pada model-model Tapis Inuh pada umumnya. Ketika segulung Tapis diwariskan pada generasi berikutnya, dikatakan bahwa kekuatan spiritual dan kekuatan gaib terkumpul dan menjadi sebuah pusaka, sebuah peninggalan yang dipuja-puja, dan harus diperlakukan dengan penghormatan sepenuhnya. Saat ini, dua tapis serupa yang keduanya dibeli pada awal abad ke-20 tersimpan baik di museum Belanda (Totton, 2009).

\footnotetext{
${ }^{4}$ Suku Komering adalah satu klan dari Suku Lampung yang berasal dari Kepaksian Skala Brak yang telah lama bermigrasi ke dataran Sumatera Selatan pada sekitar abad ke-7 dan telah menjadi beberapa Kebuayan atau Marga. Nama Komering diambil dari nama Way atau Sungai di dataran Sumatera Selatan yang menandai daerah kekuasaan Komering (http://id.wikipedia.org/wiki/Suku Komering, diakses 4 Desember 2012)
} 
Analisis umur Inuh dapat diidentifikasi dari ornamennya. Ketika pada beberapa Tapis Inuh yang berumur tua terdapat kesamaan dengan ornamen Mesir. Kesamaan ornamen yang dimaksud adalah banyaknya bentuk-bentuk ragam hias yang menyerupai Piramid. Apabila diinterpretasikan berdasarkan teori masuknya Islam, maka periode adanya Inuh di masa lampau dapat sedikit diperkirakan, yakni sebelum abad ke-13 (Wawancara dengan Zulkifli Yusbir, 30 Oktober 2012). Asumsi ini tentu bersandar pada adanya pengaruh Islam, dalam hal ini Mesir, pada ornamen Inuh. Sebelum masuknya Islam, atau jika dilihat dari ornamen Inuh dengan usia yang lebih tua, maka cenderung ditemukan ragam hias atau ornamen yang berupa fauna, bukan berupa bangunan piramid. Tentu ini hanya argumen yang spekulatif yang muncul karena keterbatasan teknologi dan data arkeologis. Dari berbagai asumsi yang ada, belum dapat diambil sebuah kesimpulan kapan Inuh pertama kali muncul, namun ada sedikit interpretasi yang masuk akal, yakni asumsi bahwa awal mula Inuh terkait dengan masyarakat pesisir ${ }^{6}$. Adanya unsur

\section{Berdasarkan hipotesis Ahmad Mansur Suryanegara, masuknya Islam dapat diikhtisarkan menjadi tiga teori besar. Pertama, teori Gujarat, India. Berdasarkan teori pertama, Islam dipercayai datang dari wilayah Gujarat - India melalui peran para pedagang India muslim pada sekitar abad ke-13 M. Kedua, teori Makkah. Islam dipercaya tiba di Indonesia langsung dari Timur Tengah melalui jasa para pedagang Arab muslim sekitar abad ke-7 M. Ketiga, teori Persia. Islam tiba di Indonesia melalui peran para pedagang asal Persia yang dalam perjalanannya singgah ke Gujarat sebelum ke nusantara sekitar abad ke-13 M. Jika mengacu pada teori pertama, yakni Islam masuk pada abad ke-13, maka Tapis Inuh boleh jadi sudah ada sebelum itu.}

6 Daerah Lampung yang merupakan bagian dari Asia Tenggara memang menjadi daerah tujuan penting terutama bagi saudagarsaudagar Arab, India, Portugis, Cina, Spanyol, dan Belanda. Masuknya berbagai pengaruh budaya, boleh jadi turut mempengaruhi laut dan pengaruh ornamen Timur-Tengah (piramid), menguatkan bahwa Inuh muncul dari daerah pesisir. Umum diketahui bahwa interaksi dan akulturasi justru banyak terjadi di daerah pesisir. Artinya, awal mula kemunculan Inuh di daerah pesisir atau muncul di tengah masyarakat beradat Sai Batin, bisa disepakati.

Orang pesisir sebagai masyarakat pendukung Inuh memiliki kecenderungan untuk lebih maju daripada masyarakat pedalaman. Interaksi terhadap pengaruh luar, dalam hal ini pedagang-pedagang asing di masa lampau, lebih intens terjadi. Melalui interaksi dengan pengaruh luar atau dengan kebudayaan lain inilah, terjadi akulturasi yang secara langsung maupun tidak langsung mempengaruhi ilmu pengetahuan, cara pandang, dan teknologi masyarakat pesisir. Masyarakat Sai Batin yang mampu menghasilkan Inuh merupakan representasi dari pandangan hidup mereka terhadap lingkungannya (sekitar laut), dan kemajuan unsur-unsur budaya yang mereka miliki. Inuh yang ragam hias maupun jenisnya yang tidak sebanyak tapis Pepadun, bukan menggambarkan tumpulnya pengetahuan masyarakat Sai Batin, namun hal tersebut terjadi karena Inuh dibuat justru dengan tingkat kerumitan yang lebih tinggi dari Tapis Pepadun. Jika digeneralisasikan, Inuh memperlihatkan keterampilan dan ketekunan dari masyarakat Sai Batin. Sayangnya, jejak sejarah Inuh tidak bisa ditelusuri secara utuh karena keterbatasan peninggalan Inuh dan proses pewarisannya sempat terputus sekian laman. Asumsi yang muncul, bahwa keterputusan pewarisan dan keterbatasan peninggalan Inuh karena meletusnya Gunung Krakatau pada tahun 1883. Letusan Krakatau tersebut menyapu hampir seluruh pesisir

perkembangan teknologi pertenunan di Lampung. Sejarawan Belanda, Van Deer Hoop, mengemukakan bahwa masyarakat Lampung telah mengenal tenun/tekstil sejak abad ke-2 sebelum masehi, yaitu kain tenun sistem kait dan kunci (Intani, 2006:1) 
Lampung. Inuh yang muncul dan berkembang di tengah masyarakat pesisir, boleh jadi ikut musnah oleh bencana tersebut.

\section{Perkembangan Tapis Inuh}

Data yang lebih akurat dapat ditelusuri dari keterangan yang lebih modern, Inuh muncul kembali atau baru ditemukan kembali pada 1960-an oleh seorang kolektor barang antik. Menurut keterangan Zulkifli Yusbir, seorang ahli kain dan kolektor barang antik, kain Inuh baru ditemukan kembali pada tahun 1965 oleh ayah dari Zulkifli. Mulai tahun 1965 hingga 1970, Zulkifli mengoleksi kain dengan ciri-ciri seperti Inuh. Ayah Zulkifli mendapatkannya Inuh dari proses tukarmenukar atau biasa disebut barter. Ketika itu orang-orang yang memiliki kain Inuhyang ketika itu belum dikenal dengan nama Inuh-banyak di antaranya yang tidak tahu-menahu tentang asal-usul ataupun namanya (Wawancara dengan Zulkifli Yusbir, 30 Oktober 2012).

Zulkifli kemudian melanjutkan jejak ayahnya untuk mengoleksi dan mengumpulkan kain-kain Inuh. Ia melanjutkan pencarian kain-kain Inuh ke pelosok-pelosok daerah. Inuh asli yang bisa digolongkan sebagai barang antik merupakan kain yang sulit untuk ditemukan. Zulkifli mencarinya ke berbagai daerah dengan menggunakan jaringan yang telah dikenal dari sang ayah. Beberapa orang yang ditemui Zulkifli terkadang memang memiliki Inuh, namun tidak banyak yang kuasa menjual Inuh. Keengganan tokoh adat atau beberapa kalangan masyarakat untuk menjual Inuh buatan lama karena menjual Inuh dinilai kurang pantas. Keengganan beberapa orang untuk menjualnya dikarenakan orang-orang yang memiliki Inuh jika ditelusuri, memiliki latar belakang hubungan dengan kalangan raja atau bangsawan Lampung terdahulu. Apabila mereka menjual Inuh bisa dinilai miring oleh pihak keluarga. Hal tersebut terjadi karena bagi sebagian masyarakat
Lampung, Tapis memiliki unsur sakral dan merupakan kepemilikan bersama dalam suatu komunitas (Wawancara dengan Zulkifli Yusbir, 30 Oktober 2012).

Zukifli sendiri baru mulai mengenalkan dan mengangkat kembali Inuh pada tahun 2005. Usaha yang dilakukan di antaranya dengan mencoba memproduksi kembali Inuh dengan cara yang lebih praktis dan komersial. Awal mula diangkat kembalinya Inuh dilatarbelakangi oleh sebuah seminar Batik yang diadakan oleh Iriana Trimurti Ryacudu di Hotel Indrapuri-Lampung. Saat itu, Iriana Trimurti Ryacudu selaku Kepala Sub Direktorat Ekspor Aneka Industri Departemen Perdagangan, mengutarakan keluhan bahwa barang-barang tradisional Lampung cenderung berat, kemudian benang emas kurang disukai masyarakat luar negeri, dan faktor kain berunsur metal menjadi kendala dalam pengiriman. Zulkifli Yusbir diundang dalam acara tersebut, dan menunjukkan kain ikat khas Lampung yang dikenal sebagai Inuh yang berbahan sutera. Iriana Ryacudu menunjukkan ketertarikannya, dan sejak itu Zulkifli mulai memperkenalkan Inuh pada khalayak luas, yang dimulainya dari Lampung Selatan. Pemerintah Lampung Selatan menunjukkan ketertarikan yang sama, terutama istri Bupati Lampung Selatan ketika itu. Sejak saat itu, mulailah dikembangkan dan diperkenalkan kembali Inuh, di antaranya dengan mendatangkan beragam mesin produksi untuk membuat Inuh kembali dalam jumlah besar. Alasan Zulkifli mengembangkannya di Lampung Selatan karena saat itu ia berdomisili di Lampung Selatan, maka pengembangan Inuh pun dimulai dari sana. Inuh aslinya kemungkinan berasal dari Krui, Lampung Barat, namun betul adanya jika Inuh merepresentasikan karya Saibatin (masyarakat pesisir Lampung), termasuk pula di Lampung Selatan (Wawancara dengan Zulkifli Yusbir, 30 Oktober 2012).

Informasi lain tentang kemunculan kembali Inuh dikemukakan dalam majalah Gema Industri Kecil edisi XXII/Juni 2008 
yang menjelaskan bahwa Inuh baru muncul kembali di tahun 2000-an. Informasi tentang Inuh yang terputus mata rantainya mulai bisa dikuak. Ketika ada beberapa masyarakat Lampung yang berkunjung ke luar negeri (Amerika Serikat dan Australia), mendapatkan informasi soal kain tenun ikat Inuh dari buku dan fisik produk kain Inuh. Berdasarkan informasi tersebut, Dekranasda Kabupaten Lampung Selatan bekerja sama dengan Pemangku Adat setempat, Pemerintah Daerah, dan beberapa individu yang masih memiliki pengetahuan dan keterampilan proses dan pembuatan kain Inuh, khususnya masyarakat Kalianda Lampung Selatan berusaha menghidupkan dan menumbuhkan kembali kain tersebut. Setelah dikembangkan kembali, Tapis Inuh mengalami perubahan fungsi. Jika dahulu tapis Inuh digunakan dalam acara adat, maka saat ini telah digunakan untuk produk fashion dan telah memperoleh persetujuan dari pemangku adat. Prospek untuk mengkomersilkan kain Inuh pun menjadi lebih terbuka (Gema Industri Kecil. Edisi XXII/Juni 2008).

\section{Makna Ragam Hias pada Inuh}

Identifikasi Inuh dapat pula dilihat dari cara pembuatan serta motifnya. Inuh dibuat dengan sutera dengan menggunakan metode ikat dan sulaman tangan. Pembuatan Inuh melalui tahapan-tahapan yang rumit dan memerlukan waktu yang lama untuk pengerjaannya. Benang untuk Inuh menggunakan benang sutera yang warnanya dicelup dengan warna alam. Proses pencelupan benang untuk Inuh memerlukan waktu kurang lebih satu tahun. Benang dicelup helai per helai sesuai dengan pola warna yang diinginkan, kemudian dijemur. Warna yang digunakan untuk Inuh diambil dari warna alami, seperti buah-buahan; manggis, kunyit, duren, buah pinang muda, daun pacar, kulit kayu kejal, dan lain sebagainya. Warnawarna pada kebanyakan Inuh muncul dari hasil benang celupan warna yang tekniknya mengikuti resep celup keluarga. Mungkin dari teknik celup keluarga ini dapat diketahui asal mula dari mana kain Inuh. Sayangnya, tidak ada satu pun kolektor sebelum akhir abad ke-20 yang mendokumentasikan detail-detail kain tapis yang mereka beli dari keluarga atau penjualnya (Totton, 2009 dan Wawancara dengan Zulkifli Yusbir, 30 Oktober 2012). Inilah salah satu faktor yang membuat pengerjaan Inuh memerlukan waktu yang lama dan memerlukan keterampilan khusus yang tidak sembarangan. Setelah proses pencelupan dan pewarnaan selesai, kemudian benang dimasukkan pada pakannya (benang vertikal). Benang dimasukkan satu per satu, kemudian dipadatkan. Pola kerja sulam pada Inuh hampir mirip dengan pola kerja menganyam (benang dimasukkan, lalu diangkat). Hanya saja, pada Inuh pengangkatan benang benar-benar diperhitungkan panjangnya.

Ketepatan sulaman dan motif yang dibentuk pada Inuh justru dapat terjadi karena kepandaian serta kebiasaan si pembuatnya. Pembuat sudah melakukan perkiraan dan pengonsepan di dalam benaknya sebelum benang tersebut disulam, bahkan pengonsepan sudah terbayang ketika benang sutera dicelup dengan warna. Oleh karena itu, pembuatan Inuh memiliki tingkat presisi yang sangat tinggi.

Cara pembuatan dan motif Inuh menjadi keunikan tersendiri. Orisinalitas Inuh begitu terjaga karena tidak mungkin membuat motif dan pola yang betul-betul sama dengan metode pembuatannya yang serumit itu. Pembuat Inuh di masa lampau boleh jadi bukan orang sembarangan, melainkan punya keahlian tertentu. Pengonsepan bentuk Inuh yang sudah dirancang ketika si pembuat memberi warna pada benang memperlihatkan kepandaian dan tingkat abstraksi yang tinggi semenjak pengonsepannya dalam pikiran si pembuat. Selain itu, Inuh hanya dibuat oleh satu orang. Ini menunjukkan bahwa seorang pembuat Inuh di masa 
lampau memiliki banyak keahlian; mulai dari memintal, memberi dan mencelup warna, dan keahlian yang paling utama, yaitu menyulam menjadi motif tertentu. Menurut Zulkifli Yusbir selaku kolektor dan ahli kain, untuk meniru teknik pembuatan Inuh secara otentik dengan metode lama, dengan sumber daya manusia sekarang ini, setidaknya diperlukan tenaga 5 sampai 7 orang pekerja. Itu pun bisa memakan waktu 1 hingga 2 tahun. Hal yang paling menyulitkan dalam pembuatan Inuh adalah teknik pencelupan warna pada benang yang harus helai per helai dan disesuaikan dengan ragam hias dan motif yang ingin dibentuk (Wawancara dengan Zulkifli Yusbir, 30 Oktober 2012).

Berdasarkan metode celup benang helai per helai, kain Inuh cenderung memiliki warna-warna yang bernuansa gelap. Hal ini terjadi karena warna kain Inuh diambil dari warna-warna yang berasal dari alam. Kondisi ini agak berbeda dengan Tapis-tapis jenis lain yang warnanya cenderung lebih cerah karena menggunakan benang emas dan perak pada motif dan ragam hiasnya.
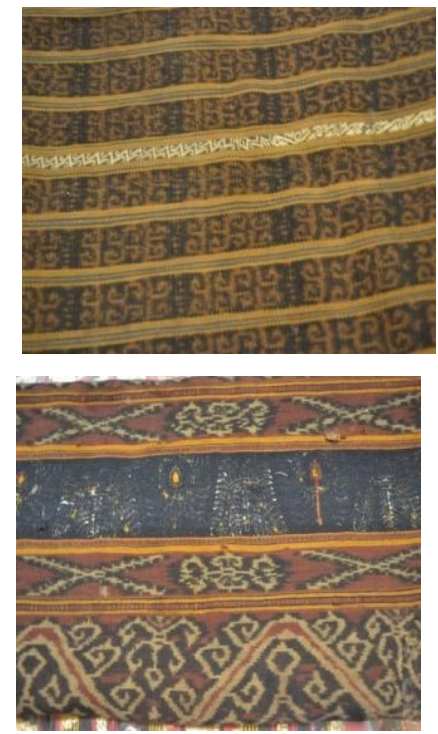

Gambar 2. Kain Inuh yang berumur \pm 400 tahun.

Sumber: Dok. BPNB 2012.
Inuh yang dibuat dengan teknik celup benang sutera dan sulaman tangan, saat ini sudah jarang ditemukan, jika pun ada, kain Inuh itu merupakan kain antik yang sudah berumur tua, antara 400 sampai 500 tahun. Oleh karena itu, Inuh bisa disebut sebagai "Rajanya Tapis" karena usianya yang memang sudah begitu tua. Koleksi kain Inuh yang sudah berumur tua bisa mencapai angka 2 milyar rupiah (Wawancara dengan Zulkifli Yusbir, 30 Oktober 2012). Mahalnya harga Inuh ditentukan berdasarkan kerumitan motif sulam tangan yang dibuat. Uniknya, kainkain Inuh yang telah berumur tua ini, tidak bisa dicuci. Jika kain Inuh dicuci, maka bentuknya akan hancur. Cara terbaik untuk perawatannya cukup dengan disimpan di tempat yang suhunya terjaga dan disertai dengan sejenis rempah agar kondisinya tetap baik. Menurut keterangan Zulkifli, kain-kain Inuh yang berumur sangat tua memiliki unsur-unsur mistis tersendiri. Inuh hampir memiliki kesamaan dengan keris, yang konon pada tiap-tiap kainnya terdapat "makhluk penjaganya". Dalam kepercayaan-kepercayaan tradisional di Nusantara memang lumrah adanya anggapan bahwa selalu ada "makhluk penjaga" pada barang-barang yang dianggap sakral.

Kain Inuh tidak bisa disamakan dengan kain Kapal. Sekalipun kain Kapal merupakan karya masyarakat pesisir (Sai Batin), namun Inuh berbeda dengan kain Kapal. Kain kapal biasanya hanya digunakan sebagai kain saja atau sekadar taplak, sementara Inuh bisa digunakan menjadi pakaian. Kain Kapal sangat jarang atau hampir tidak mungkin dijadikan pakaian karena bentuk motifnya terlalu besar, sehingga akan terlihat kurang bagus ketika dijadikan pakaian. Walaupun berbeda dengan kain Kapal, namun Inuh menggunakan ragam hias berbentuk kapal. Ragam hias kapal pada Inuh sering disandingkan dengan ragam hias wayang khas Lampung (Wawancara dengan Zulkifli Yusbir, 30 Oktober 2012). 
Inuh pun berbeda dengan Tapis pada umumnya. Sebagian besar Tapis menggunakan metode sulam kait, serta benang Pakan dan Lungsi. Sementara Inuh tidak menggunakan Pakan (benang vertikal) dan Lungsi (benang Horizontal). Dahulu memang sudah dikenal sistem pakan-lungsi, namun untuk Inuh, benang dimasukkan dengan tangan satu per satu (dicungkit). Proses pembuatannya yang sulit dan rumit membuat Inuh memiliki nilai seni dan sejarah yang tinggi. Inuh merupakan salah satu dari sedikit kain ikat di dunia yang menggunakan bahan sutera. Proses pembuatan kain ikat, hampir sama dengan Bali yang disebut Grinsing. Grinsing pun memiliki harga yang sangat mahal, bisa mencapai puluhan juta (Wawancara dengan Zulkifli Yusbir, 30 Oktober 2012).

Motif Inuh jenis baru saat ini, atau yang diproduksi secara luas oleh beberapa pengusaha kain, cenderung telah menyimpang dari pakem aslinya dan metode pengerjaannya pun sudah dibuat menjadi lebih sederhana, yakni motif dan ragam hias dipola terlebih dahulu dengan cara dicap. Motif-motif Inuh saat ini justru banyak dicampur-baurkan dengan motif khas Pepadun, seperti gajah atau hewanhewan darat. Padahal, Inuh yang dibuat oleh masyarakat Sai Batin selalu terkait dengan kehidupan sekitar laut, seperti cumi, plankton, dan kapal. Kapal atau perahu menggambarkan perjalanan kehidupan manusia, perjalanan kehidupan manusia ini beriringan dengan makhluk Tuhan yang lain, yaitu tumbuhan, hewan, dan lingkungan sekitar. Jika salah satu unsur dari manusia, tumbuhan, dan hewan ini putus atau tidak terjaga dengan baik, maka hancurlah dunia. Konsep ini identik dengan keseimbangan hidup antara unsur makro dan mikro kosmos.

Pada kain-kain Inuh selalu terkandung pesan atau semacam cerita, seperti yang ditunjukkan oleh motif kapal. Pada jenis kain Pelepai dan Ketibin, selalu terdapat motif kapal besar, pohon, binatang, dan manusia. Motif tersebut menggambarkan kehidupan manusia, dan dari perspektif lain juga menggambarkan perjalanan Nabi Nuh dalam mengarungi laut. Ornamen pada Inuh pun menggunakan ornamen sejenis seperti pada kain Pelapai dan Ketibin yang sudah bertahan lama. Hanya saja, pada Inuh tidak ditemukan motif pohon kehidupan. Tiaptiap daerah di Lampung, sama-sama menggunakan motif serupa kapal, namun tiap daerah memiliki ciri khas motif kapal yang bentuknya berlainan. Tiap-tiap kain selalu mempunyai nilai-nilai filosofis yang maknanya disembunyikan pada bentuk, motif, dan ragam hias kain.

Berikut ini dijelaskan mengenai ragam hias dan motif yang biasanya terdapat pada Inuh. Ragam hias pada Inuh sebetulnya cenderung didominasi oleh bentuk-bentuk yang abstrak, namun penggolongan berikut ini berdasarkan interpretasi penulis terhadap bentuk yang bisa ditangkap secara kasat mata.

\section{a. Hewan Laut}

Hewan laut didesain tidak semirip seperti bentuk aslinya dan biasanya menampakkan potongan tubuhnya dari sisi atas dan samping. Jenis hewan laut yang dapat diketahui di antaranya adalah ikan, kepiting, cumi-cumi, udang, ubur-ubur, dan plankton. Seperti yang telihat di gambar, ragam hias yang nampak cenderung abstrak. Motif dan ragam hias Inuh di bawah ini merupakan motif dari Inuh yang telah berusia kurang lebih 300 tahun. Bentuknya yang abstrak memperlihatkan tingkat imajinasi masyarakat pesisir di masa lampau dalam menggambarkan laut beserta faunanya. Tingkat abstraksi ini tentu tidak bisa disamakan dengan masyarakat modern saat ini, dimana gambaran mengenai laut bisa diperoleh dengan mudah dan utuh. 


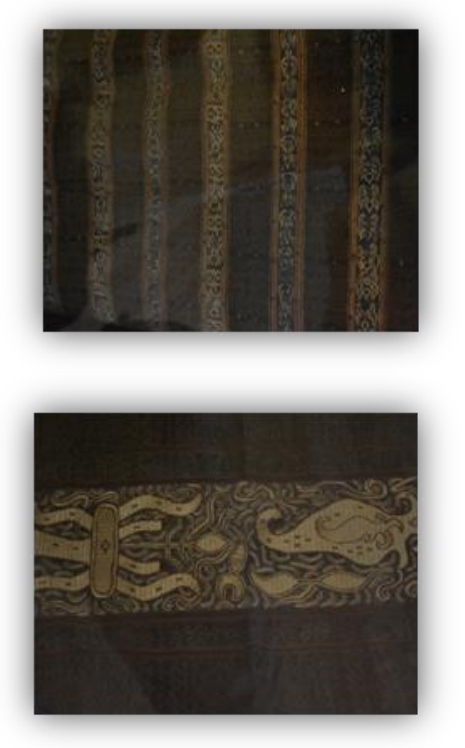

Gambar 3. Inuh Bermotif Hewan Laut. Sumber: Dok. BPNB 2012.

\section{b. Gelombang Laut}

Gelombang laut merupakan motif berupa untaian segi tiga yang tersusun vertikal dan horizontal. Untaian segi tiga menggambarkan jenis laut rendah. Sementara untuk gelombang laut besar digambarkan dalam bentuk motif sulur gulung dan pucuk pakis yang berselangseling (Firmansyah dkk, 1996: 42).

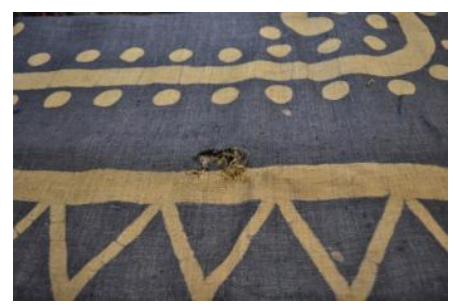

Gambar 4. Inuh Bermotif Gelombang.

Sumber: Dok. BPNB 2012.

\section{c. Sulur}

Sulur merupakan sulaman berbentuk tali. Ragam hias bentuk ini umum ditemui pada Tapis Inuh dan Tapis Cucuk Andak. Bentuk sulur berupa ikatan tali yang berliku-liku yang selintas seperti rangkaian yang tidak terputus. Makna simbol dari ragam jenis ini adalah ikatan kekeluargaan harus dijalin dengan siapa pun serta harus tetap utuh tidak terputus. Maksudnya, dengan terjalinnya ikatan kekeluargaan diharapkan masyarakat Lampung tidak akan menghadapi kesusahan di mana pun mereka berada. Pemaknaan ini terkait pula dengan kondisi masyarakat Lampung yang cenderung terbuka dalam menerima kedatangan etnis lain (Intani, 2006: 39).

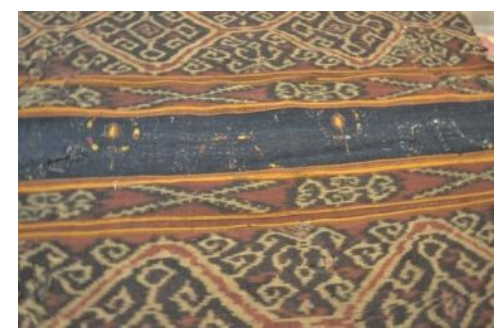

Gambar 5. Motif Gelombang Laut dan Sulur.

Sumber: Dok. BPNB 2012.

\section{d. Kapal}

Beberapa sarjana menafsirkan kebanyakan citra kapal ini sebagai kiasan perjalanan jiwa yang pergi menyeberangi batas kematian. Namun, kita juga bisa membaca cerita dalam salah satu sulaman Inuh secara harfiah. Kekayaan para elit daerah Lampung secara dekat diasosiasikan dengan keuletan dan usaha keras mereka dalam bidang bahari. Contohnya, perkebunan lada bukan saja menyedot para pembeli rempah-rempah melainkan juga para pedagang budak (Totton, 2009). Misalnya ada suatu motif yang menggambarkan tawanan-tawanan yang dibelenggu dalam gudang kapal, orang-orang malang yang akan dijual untuk bekerja di perkebunan lada di Lampung atau semacam kapal tertawan yang dibawa ke pelabuhan oleh kapal yang menawannya. Seperti halnya komoditas yang diperoleh dari seberang lautan sangat berharga bagi upacara kenaikan status sosial. Dari kondisi ini dapat digambarkan bahwa barang tekstil digunakan untuk keperluan ritual dapat secara jelas merepresentasikan pula kontak dengan wilayah seberang lautan (Totton, 2009). 
Kapal merupakan ciri khas pada kain khas Lampung yang mengandung arti simbolis dan filosofis terkait dengan kehidupan masyarakat Lampung. Kapal menggambarkan perjalanan hidup seperti sebuah kapal yang bergerak dari satu tempat ke tempat lain, dari suatu keadaan ke keadaan lainnya. Menggambarkan perjalanan hidup manusia; dari lahir ke dunia ini, memasuki masa inisiasi ke tingkat kedewasaan, perkawinan, dan kematian. Setiap tingkatan dalam pola kehidupan selalu menghadapi suatu masa krisis dan mencoba melawan dan menghindari malapetaka yang kemungkinan akan timbul. Melalui persepsi itu, masyarakat Lampung memandang perlu adanya upacara agar tidak mengalami kesulitan dan mendapat keselamatan (Kartiwa, T.th: 6).

Ragam hias kapal merupakan unsur dominan dalam kain adat Lampung. Bentuk kapal dan warna juga memiliki pemaknaan yang berbeda-beda. Motif kapal dengan warna merah menggambarkan kesakralan dan hubungan dengan dunia atas, kapal berwarna biru menggambarkan hubungan dengan dunia bawah yang profan, selain ada dunia ketiga yaitu dunia tempat manusia dan alam lingkungannya, fauna dan flora sebagai dunia tengah. Warna-warna simbolis beserta muatan atau isi kapal mewakili filosofis unsur makro kosmos dan mikro kosmos secara menyeluruh (Kartiwa, T.th: 7).

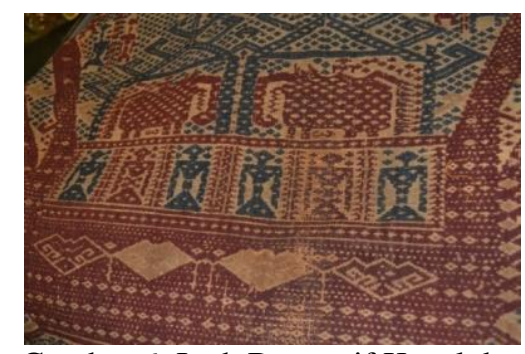

Gambar 6. Inuh Bermotif Kapal dan Manusia

Sumber: $\quad$ Dok. BPNB 2012

\section{e. Perahu}

Makna ragam hias perahu memiliki kemiripan makna dengan kapal. Hias kapal melambangkan fase kehidupan, sementara perahu melambangkan peralihan seseorang menuju derajat yang lebih tinggi. Masyarakat Lampung memandang perahu sebagai simbolisasi dari kendaraan arwah nenek moyang dari dunia bawah menuju dunia atas (Firmansyah dkk, 1996:34).

\section{Penggunaan dan Nilai Budaya pada Inuh}

Inuh biasa digunakan untuk upacara. Inuh dipakai sebagai kain senjang atau kain sarung untuk wanita, khususnya bagi kalangan wanita beradat Sai Batin (pesisir). Inuh bukan kain yang bisa dipakai oleh sembarang orang. Dahulu, Inuh dipakai oleh tiga golongan; Ibu Suri, kalangan kerajaan, dan pemangku adat. Inuh biasanya digunakan oleh Ibu Suri. Inuh yang dipakai oleh Ibu Suri ini memiliki tingkat kerumitan dan keindahan motif yang berbeda dibandingkan dengan Inuh yang biasa dipakai oleh kalangan kerajaan dan pemangku adat. Inuh yang dipakai oleh Ibu Suri biasanya dibuat oleh wanita yang telah memiliki keterampilan khusus dalam membuat Inuh, terutama para wanita yang telah berumur tua dan memiliki banyak pengalaman juga ilmu yang memadai dalam pembuatan tapis (Wawancara dengan Kepala Museum Ruwa Jurai, 26 November 2012). Adapun rakyat biasa sebetulnya ada pula yang memakai Inuh, tetapi dengan bentuk yang lebih sederhana, yaitu Inuh sambung atau kain yang penenunan sulam tangannya tidak sejiwa, tetapi berupa sambungan (tidak utuh). 


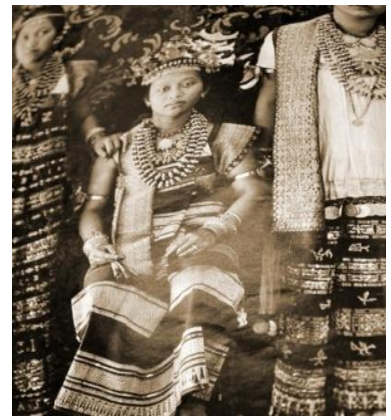

Gambar 6. Wanita Lampung Menggunakan Tapis Inuh Sumber: Dok. BPNB

Stratifikasi sosial masyarakat dapat pula dilihat dari bahan pembuat Inuh yang terbuat dari sutera. Bahan sutera tentu tidak bisa didapatkan dengan mudah, hanya kalangan tertentu saja yang mempunyai kemampuan untuk membeli sutera. Artinya, sangat mungkin bahwa para wanita yang membuat atau pun memakai Inuh tentulah bukan rakyat biasa, tetapi kalangan tertentu yang setidaknya serba berkecukupan atau sangat mungkin berasal dari kalangan kerajaan.

Pemakaian Inuh turut merepresentasikan stratifikasi sosial masyarakat Sai Batin. Semakin rumit Inuh yang dipakai, semakin tinggi stratifikasi sosial pemakainya. Semakin besar kainnya pun turut mempengaruhi kerumitan motif. Artinya, pemakai yang stratifikasi sosialnya lebih tinggi cenderung memakai Inuh yang ukurannya lebih besar.

Aturan dalam pemakaian Inuh pun lebih ketat daripada pengaturan penggunaan kain Tapis pada masyarakat Lampung Pepadun (pedalaman). Inuh yang digunakan oleh Penyimbang (kepala adat) pada masyarakat beradat Sai Batin selalu diwariskan secara turun-temurun pada anak tertua. Anak-anak Penyimbang yang lain tidak pernah membuat Inuh dengan bentuk atau motif yang lain. Apabila Inuh tersebut rusak dalam pewarisannya, maka barulah dibuat Inuh yang baru dengan bentuk dan motif yang sama, sementara Inuh yang telah rusak tidak digunakan lagi dan disimpan. Dengan kata lain, satu keluarga Penyimbang hanya memiliki satu jenis Inuh saja (Wawancara dengan Kepala Museum Ruwa Jurai, 26 November 2012). Hal ini pula yang menyebabkan Inuh di Lampung jumlahnya sangat terbatas.

Inuh berbeda dengan Tapis pada masyarakat beradat Pepadun. Dalam Tradisi Pepadun, Penyimbang yang memiliki beberapa anak laki-laki, bisa membuat marga atau penyematan gelar tersendiri dari beberapa anak lelakinya. Anak tertua berhak mendapat pewarisan gelar dan kedudukan sebagai Penyimbang, namun anak lelaki yang lain pun bisa mendapatkan gelar atau marga sendiri asalkan berdasarkan persetujuan kakak tertua. Pengangkatan gelar tersebut biasanya dilakukan melalui prosesi upacara adat Begawi. Dari Tradisi semacam inilah, Tapis pada masyarakat Pepadun bukan sekadar pewarisan secara turun-temurun dari ayah ke anak lelaki tertua (tapis milik ibu kepada menantu perempuan), namun tiap-tiap keluarga anak lelaki bisa membuat tapisnya sendiri-sendiri sesuai dengan kedudukannya. Tentu saja pembuatan Tapis ini dilakukan oleh kaum wanita. Dengan demikian, dapat lah dimaklumi mengapa jumlah Inuh lebih terbatas, karena Inuh tidak bisa dibuat sembarangan oleh setiap keluarga, melainkan diwariskan secara turuntemurun hanya kepada istri dari anak lakilaki tertua.

Inuh yang dibuat hanya oleh kaum wanita merepresentasikan keterampilan kaum wanita dan penghargaan wanita dalam tradisi Lampung. Tapis dibuat oleh wanita dan dipakai hanya oleh wanita. Para wanita beradat Pepadun dan Sai Batin semenjak gadis sudah dibiasakan untuk membuat tapis, ketika mereka beranjak dewasa dan akan dipinang oleh lelaki, maka tapis buatan si wanita menjadi simbolisasi seberapa layak wanita tersebut untuk calon suaminya. Ketika akan dilamar, wanita Lampung selalu dipingit selama beberapa bulan. Dalam masa pingitannya itu, wanita Lampung biasanya membuat Tapis dengan tangannya sendiri 
untuk kemudian dipakainya ketika akan memasuki upacara adat perkawinan. Hal ini berlaku umum, baik pada masyarakt beradat Sai Batin maupun masyarakat beradat Pepadun (Wawancara dengan Kepala Museum Ruwa Jurai, 26 November 2012).

Tapis Inuh yang dibuat oleh calon pengantin wanita bisa menjadi pemaknaan tersendiri bagi keluarga calon pengantin pria. Inuh menggambarkan keuletan dan ketekunan dari wanita pembuatnya. Calon pengantin pria dalam tradisi Lampung, terutama yang menyandang status sebagai anak laki-laki tertua, biasanya sangat mempertimbangkan matang-matang calon istrinya. Penilaian calon istri bisa dilihat dari tapis yang dibuat. Semakin banyak dan piawainya seorang wanita dalam membuat tapis, semakin dinilai tinggi kemampuannya di mata pria dan layak pula untuk dijadikan istri. Kepandaian dalam membuat Tapis, turut memberi gambaran keuletan, ketekunan, dan keterampilan wanita yang nantinya sangat diperlukan saat membangun rumah tangganya kelak.

Calon suami yang berstatus sebagai anak laki-laki tertua menganggap pentingnya seorang istri yang memiliki kepandaian dan keuletan, karena di tangan istrinya itu keluarga besar sang pria akan turut ditopang, maka si istri harus pandai dalam mendukung suaminya. Kesuksesan suami didukung oleh istri. Suami yang menyandang nama besar keluarga dan menjadi pimpinan marganya tentulah memerlukan kemampuan yang lebih, untuk itulah peran istri yang pandai dan terampil sangatlah diperlukan. Kondisi demikian juga merepresentasikan betapa dalam adat Lampung, wanita memperoleh penghormatan yang tinggi. Kerumitan dan tingginya nilai artistik dari Inuh, serta pemakaiannya oleh kaum wanita menggambarkan bahwa wanita Lampung sangat dihargai (Wawancara dengan Kepala Museum Ruwa Jurai, 26 November 2012).

\section{PENUTUP}

Inuh merupakan salah satu jenis kain Tapis yang muncul dan dikembangkan di tengah-tengah masyarakat beradat Sai Batin (pesisir). Inuh dibuat dengan cara tenun ikat, menggunakan bahan benang sutera yang pewarnaannya dengan teknik celup tradisional. Inuh memiliki perbedaan dengan kain Tapis yang ada dan berkembang di tengah masyarakat Lampung beradat Pepadun (pedalaman). Perbedaan yang paling menonjol terletak dari motif dan bahan yang digunakan. Jika Tapis yang muncul di tengah masyarakat Pepadun menggunakan benang emas dan benang perak, maka Inuh menggunakan benang sutera. Motif yang digunakan pada Inuh pun hanya meliputi motif-motif bernuansa laut yang merepresentasikan cara pandang masyarakat pesisir terhadap lingkungannya. Awal mula kemunculan Inuh belum bisa dipastikan, namun berdasarkan identifikasi pada kain Inuh yang diperkirakan telah berumur tua (antara 300 sampai 500 tahun), dapat diambil hipotesis sementara, bahwa Inuh kemungkinan telah muncul pada abad ke17. Hipotesis tersebut masih sangat rapuh mengingat hanya berdasarkan pada perkiraan dan analisis ahli kain, bukan berdasarkan hasil uji karbon pada peninggalan Inuh yang masih ada. Namun demikian, berdasarkan motif, Inuh hampir bisa dipastikan memang muncul dan berkembang di tengah masyarakat pesisir yang notabene sangat berdekatan dengan unsur-unsur laut.

Keterbatasan dan kelangkaan Inuh yang terjadi dipengaruhi oleh empat faktor. Pertama, dalam sebuah keluarga Penyimbang, pewarisan Inuh hanya diberikan pada anak laki-laki tertua (pada praktiknya dipakai oleh istri dari si anak tertua). Anak-anak yang lain dari si Penyimbang, tidak memiliki hak untuk mewarisi Inuh. Artinya, satu keluarga penyimbang hanya memiliki satu kain Inuh. Kedua, dalam sebuah keluarga Penyimbang, Inuh tidak serta merta bisa 
direproduksi atau dibuat baru. Reproduksi hanya dilakukan jika Inuh yang ada telah rusak, itu pun dengan konsekuensi bahwa Inuh yang rusak harus disimpan. Ketiga, keterputusan jejak sejarah, peninggalan, dan pewarisan cara pembuatan Inuh. Bencana Krakatau pada 1883 yang menyapu sebagian besar pesisir Lampung diperkirakan turut mempengaruhi kelangkaan dan menghambat proses pewarisan ilmu pembuatan Inuh. Keempat, dewasa ini teknik dengan cara lama sulit untuk ditiru, terutama resep pencelupan benang dan pengonsepan motif.

Bagi masyarakat pesisir Lampung, Inuh juga merepresentasikan status sosial. Di masa lampau, Inuh hanya dipakai oleh kalangan kerajaan, khususnya Ibu Suri. Semakin tinggi tingkat kerumitan Inuh, semakin tinggi status sosial si pemakainya. Dilihat dari pembuatannya, Inuh mengandung nilai-nilai keuletan, kerja keras, kecermatan, dan penghargaan terhadap kaum wanita. Bentuk penghargaan ini terlihat dari bagaimana Inuh sebagai benda bernilai seni tinggi serta diwariskan secara turun-temurun, hanya boleh dipakai oleh kaum wanita. Pembuatan Inuh pun dilakukan oleh kaum wanita. Hal ini semakin menguatkan, betapa Inuh pun menggambarkan penghargaan yang tinggi terhadap kaum wanita. Penilaian cakap atau tidaknya wanita, bisa dilihat pula dari seberapa piawai mereka dalam membuat Inuh. Penilaian ini juga menjadi pertimbangan bagi kaum pria ketika proses melamar wanita.

\section{DAFTAR SUMBER}

\section{Buku}

Daeng, Hans J. 2000.

Manusia, Kebudayaan dan Lingkungan. Yogyakarta: Pustaka Pelajar.

Firmansyah, Junaidi. et al. 1996.

Mengenal Sulaman Tapis Lampung. Bandar Lampung: Gunung Pesagi.

Holmgren, Robert J. dan Anita E. Spertus. 1989.
Early Indonesian Textiles from Three Island Cultures: Sumba Toraja Lampung. Metropolitan Museum of Art.

Intani, Ria. 2006.

Tapis Lampung. Laporan Perekaman BPSNT Bandung. Bandung.

Kartiwa, Suwati. Tanpa tahun.

Kain Kapal atau Pelepai dan Kain Tampan Khasanah Langka dari Lampung.

Koentjaraningrat. 1985.

Metode-metode Penelitian Masyarakat. Jakarta: Gramedia.

Laskito, Oki. et al. 1997/1998.

Kain Tenun Tradisional Koleksi Museum Negeri Provinsi Lampung "Ruwa Jurai". Lampung: Depdikbud.

1998/1999.

Koleksi dan Tata Pameran Lantai II Museum Negeri Provinsi Lampung "Ruwa Jurai”. Lampung: Depdikbud.

Totton, Mary Louise. 2009.

Wearing Wealth and Styling Identity: Tapis from Lampung, South Sumatera, Indonesia. New Hampshire: University Press of New England Hanover

Sairin, Sjafri. 2002.

Perubahan Sosial Masyarakat Indonesia. Yogyakarta: Pestaka Pelajar.

\section{Majalah}

Gema Industri Kecil edisi XXII/Juni 2008

\section{Informan}

Zulkifli Yusbir (48 tahun).

Kolektor barang antic dan pengusaha kain. Wawancara. Bandar Lampung, 30 Oktober 2012

Kherustika, Zuraida (53 tahun).

Kepala Museum Negeri Provinsi Lampung Ruwa Jurai. Bandar Lampung, 26 November 2012. 